\title{
UKRAINA MIĘDZY NARODOWYM IMPERATYWEM UNITARNOŚCI A EUROPEJSKĄ ZASADĄ DECENTRALIZACJI
}

\section{Ukraine between the National Imperative of Unitarity and the European Principle of Decentralisation}

This article describes the conceptual principles and analysis of the decentralisation process in Ukraine, as well as searches for the optimal model of implementing the decentralisation principles under the conditions of a unitary state. Possible directions and ways of reforming the management system, improving the functioning of local government bodies, strengthening the role of territorial communities and extending their competences are determined.

Keywords: Ukraine, decentralisation of power, local government bodies, united territorial communities.

Problem decentralizacji jako proces przeniesienia uprawnień władzy publicznej stał się dominujący w ukraińskiej polityce po Rewolucji Godności i obaleniu reżimu autorytarnego. Ten problem zyskiwał na aktualności z jednej strony na tle jednoczenia się narodu ukraińskiego przeciw agresji rosyjskiej i obrony integralności terytorialnej państwa, a z drugiej strony - w kontekście uświadomienia konieczności optymalizacji relacji między centrum a regionami, przeformatowania systemu zarzadzania, udoskonalenia funkcjonowania samorządów, wzmocnienia roli wspólnot terytorialnych i rozszerzenia kompetencji organów władzy lokalnej w podejmowaniu decyzji o ważnym znaczeniu dla regionu. 
Wydawać by się mogło, że nie powinny istnieć sprzeczności między unitarnościa jako konstytucyjnie umocowana forma ustroju państwa a decentralizacja jako procesem i rezultatem przeniesienia uprawnień w zakresie zarządzania i częściowego przekazania organom samorzadu lokalnego. Jednocześnie poszukiwanie optymalnego modelu decentralizacji, skutecznych sposobów, form i mechanizmów jej przeprowadzenia w warunkach państwa unitarnego nadal jest skomplikowane ze względu na szereg zewnętrznych i wewnętrznych czynników politycznych. Czynnikiem zewnętrznym jest przede wszystkim dążenie agresywnego sąsiada $z$ północy do utrzymania Ukrainy w sferze swego imperialnego wpływu, czynnikiem wewnętrznym zaś jest obecność regionalnych odmienności narodowo-kulturowych i społeczno-gospodarczych oraz brak precyzyjnej strategii państwa w zakresie realizacji zasady decentralizacji na gruncie krajowym.

Gwałcąc prawo międzynarodowe, łamiąc umowy i porozumienia międzynarodowe, Federacja Rosyjska dokonała aktu agresji zbrojnej przeciwko Ukrainie i zaanektowała część terytorium naszego państwa. Nie zaprzestając zbrojnego wspierania oddziałów bojowych separatystów na wschodzie Ukrainy, dokonując aktów terrorystycznych i dywersji przeciwko ludności cywilnej, Federacja Rosyjska poprzez masowe falsyfikacje i wykrzywioną interpretację wydarzeń i faktów $\mathrm{w}$ przestrzeni informacyjnej podejmuje systemowe próby prowokowania konfliktów obywatelskich, dąży do osłabienia potencjału gospodarczego Ukrainy i delegitymizacji jej władz.

W związku $z$ powyższym rosyjskie media, politycy i politolodzy narzucają ukraińskiemu społeczeństwu ideę tzw. federalizacji skierowanej na dekonstrukcję ustroju państwowego Ukrainy. Dążenie do ingerencji w sprawy wewnętrzne niepodległego państwa poprzez domaganie się wprowadzenia zmian do Konstytucji Ukrainy i przeprowadzenia „federalizacji państwa” wykazują także pierwsze osoby w Federacji Rosyjskiej ${ }^{1}$.

Dynamiczne i niestety tragiczne wydarzenia w ostatnim czasie na Ukrainie spowodowały powstanie skomplikowanego splotu sprzeczności, którego rozwiąanie jest konieczne dla rozwoju społeczeństwa. Na tle tych wydarzeń niektórzy ukraińscy politycy zaczęli nawoływać

Zob. Putin: naši voennye „vstali za spinoj” samooborony Kryma, Russkaâ služba BBC, 17 IV 2014, http://www.bbc.com/russian/russia/2014/04/140417_putin_phone_ line.shtml [dostęp: 9 lipca 2020]; Vladimir Putin: u Ukrainy est' buduŝee tol'ko $v$ slučae federalizacii, Vesti.RU, 17 XI 2014, https://www.vesti.ru/doc.html?id=2129964 [dostęp: 9 lipca 2020]. 
do federalizacji kraju, nadania tym lub innym regionom „szczególnego" statusu itp.

W rzeczywistości zmiany ustroju państwowego Ukrainy sa niecelowe, co więcej - moga zaszkodzić procesowi integracji społecznej, jedności narodowej, mobilizacji w przeciwstawieniu się agresywnej polityce naszego sasiada $z$ północy. Ukraińscy badacze ${ }^{2} \mathrm{w}$ sposób przekonujący udowodnili, że federalizacja nie tylko nie może stać się sposobem na rozwiazanie aktualnych dla Ukrainy problemów politycznych, lecz także jest sprzeczna $z$ tendencjami ogólnoeuropejskimi i ogólnoświatowymi. Błędna jest również teza, że federalizacja będzie sprzyjała procesowi decentralizacji władzy, ponieważ federacje moga być zarówno decentralizowane, jak i scentralizowane.

Warto odnotować, że zdecydowana większość państw świata (168) to sa, podobnie jak Ukraina, państwa unitarne charakteryzujące się takimi cechami podstawowymi jak zasadniczy akt prawny (lub zbiór takich aktów), którego przepisy maja nadrzędna moc prawna na całym terytorium kraju; jedyne dla całego kraju wyższe organy władzy; jednolity system ustawodawstwa; jednolite obywatelstwo; jednolity pieniądz; brak suwerenności części składowych państwa. Do typu federacyjnego należy jedynie około 30 państw. Federacjami sa przeważnie państwa, których ustrój ukształtował się w wyniku historyczno-geograficznego zjednoczenia się terytoriów. Wśród 28 krajów członkowskich Unii Europejskiej federacjami sa tylko trzy. Federacyjny ustrój państwa nie jest zatem dominujący ani w skali światowej, ani wśród państw europejskich.

Nie wytrzymuje krytyki i w sposób przekonujący obalana jest teza o rzekomej stałości i optymalności ustroju federacyjnego państwa. Rzeczą naturalna jest to, że państwa unitarne nie mają skłonności do zmieniania się $\mathrm{w}$ federacje, albowiem w warunkach braku adekwatnych przesłanek historycznych, mentalnych i prawnych mówienie o federalizacji jest niedorzeczne - „drobienie” państwa nie ma podstaw wewnętrznych ani prawnych, ani etniczno-terytorialnych. Właśnie $z$ tego powodu, pracujac nad doskonaleniem ustroju państwowego (terytorialnego), należy przyjąć jako punkt wyjścia nie opinie

2 Zob. L.M. Šestopalova, Forma deržavnogo ustroû âk matricâ socìal'nogo rozvitku, „Forum prava” 2014, nr 1, s. 526-531; Deržavne politične pravlìnnâ ì nacional'na êdnist': analitična dopovid', red. O.M. Majboroda, Kiïv 2017, s. 24-53; Û. Šajgorods'kij, Ponâttâ "transformacîa” âk ìnstrument analizu social'nih zmìn, "Osvita regionu: politologiâ, psihologiâ, komunikaciï” 2010, nr 4, s. 51-53; A.S. Matviênko, Politiko-pravovì zasadi teritorial'noï organizaciï deržavi: svitovij dosvìd i Ukraïna, İnstitut deržavi ì prava ìm. V.M. Korec'kogo NAN Ukraïni, Kiïv 2015; M.V. Tulenkov, Û.Ž. Šajgorods'kij, Politične upravlìnnâ $v$ sučasnomu suspil'stvi, Centr social'nih komunikacìj, Kiïv 2011. 
ościennych podmiotów stosunków międzynarodowych, tylko to, czy zmieniony ustrój będzie zadowalał samo społeczeństwo ukraińskie ${ }^{3}$.

Zauważmy, że także większość obywateli Ukrainy popiera ustrój unitarny i występuje przeciw idei federalizacji. Świadczą o tym wyniki badania socjologicznego przeprowadzonego przez Grupe „Rating” (badanie zostało przeprowadzone we wszystkich regionach Ukrainy, włączając Krym, w dniach 14-26 III 2014). 64 proc. badanych opowiedziało się za zachowaniem ustroju unitarnego Ukrainy. Jedynie 14 proc. poparło federacyjna formę państwa. Zwolennicy unitarnej Ukrainy liczebnie dominuja nawet w obwodach południowo-wschodnich. W południowej części kraju za ustrojem unitarnym opowiedziało się 44 proc., zaś za federacyjnym 22 proc., podczas gdy w części wschodniej - odpowiednio 45 proc. i 26 proc. W regionach zachodnich i centralnych idea federalizacji ma praktycznie znikome poparcie (3 proc. - na zachodzie kraju i 6 proc. w centrum) ${ }^{4}$.

Nawet obecnie, po długotrwałej i wyczerpującej konfrontacji zbrojnej $z$ agresorem rosyjskim, na obszarach części obwodów donieckiego i ługańskiego Ukrainy nadanie temu terytorium statusu podmiotu federacji (jako jeden $z$ wariantów rozwiązania problemu) poparło jedynie 27 proc. badanych (badanie przeprowadzono w dniach $19 \mathrm{X}-2 \mathrm{XI}$ 2018). Charakterystyczne jest to, że w przekroju regionalnym wskaźniki pozytywnego postrzegania „federalizacji” jako sposobu na rozwiązanie problemu agresji wojskowej korelują z przekonaniem części respondentów (22 proc.) o tym, że Rosja nie jest państwem agresorem wobec Ukrainy ${ }^{5}$.

Tendencje odśrodkowe, które były charakterystyczne dla okresu po 1991 roku i tworzyły niebezpieczeństwo dezintegracji (sytuacja na Krymie, lokalne referenda na Zakarpaciu i w Donbasie), zostały przezwyciężone w 1996 roku wraz z uchwaleniem Konstytucji Ukrainy ${ }^{6}$. Warto zgodzić się $z$ tezą, że decydującym argumentem na rzecz zachowania unitarnego, scentralizowanego państwa była obiektywna ko-

\footnotetext{
3 L.M. Šestopalova, Forma deržavnogo ustroû...

4 Socopros: naselenie Ukrainy protiv federalizacii strany, Newsland, 6 IV 2014, https:// newsland.com/user/4297677095/content/sotsopros-naselenie-ukrainy-protiv-federalizatsii-strany/4590276 [dostęp: 9 lipca 2020].

5 Badanie zostało przeprowadzone przez Kijowski Międzynarodowy Instytut Socjologii, Ukraińskie Centrum Badań Ekonomicznych i Politycznych im. Ołeksandra Razumkowa oraz Grupę Socjologiczna „Rating” na próbie reprezentatywnej 10 tys. mieszkańców Ukrainy, margines błędu wynosi nie więcej niż 1 proc. Socopros: naselenie Ukrainy protiv federalizacii strany...

6 Konstituciâ Ukraïni, Verhovna Rada Ukraïni, https://zakon.rada.gov.ua/laws/ show/254\%D0\%BA/96-\%D0\%B2\%D1\%80\#Text [dostęp: 9 lipca 2020].
} 
nieczność wzmocnienia uzyskanej niepodległości w warunkach dość sprzecznego etapu kończącego początkowy okres instytucjonalizacji władzy państwowej ${ }^{7}$.

Ogłoszenie Ukrainy państwem unitarnym (art. 2), określenie statusu Autonomicznej Republiki Krym (rozdz. X) i zasad samorządu lokalnego (rozdz. XI) częściowo rozwiązały problem procesów dezintegracyjnych $^{8}$. Jednocześnie wzmocnienie roli administracji lokalnych w sprawowaniu władzy państwowej i orientacja terenowych oddziałów centralnych organów władzy wykonawczej (ministerstw, komitetów państwowych itd.) w działalności zarządczej przede wszystkim na Kijów $z$ biegiem czasu doprowadziły do utworzenia dość mocnego pionu administracyjnego $z$ centrum podejmowania decyzji (w tym nawet tych o charakterze lokalnym) w stolicy. W swojej istocie system administracyjny państwa w wielu aspektach powielał system radziecki i niewiele różnił się od tego istniejącego w czasach USRR, kiedy to sekretarz partyjny sprawował faktyczną władzę w obwodzie, rejonie, mieście.

Próbę zreformowania stosunków między centrum a regionami dokonano na początku pierwszej dekady XXI wieku, nie przyniosła ona jednak oczekiwanych skutków - dźwignie wpływu na podejmowanie decyzji pozostały $w$ rękach przewodniczacych administracji państwowych. Druzgocącej porażki doznała zainicjowana przez „postpomarańczowe" władze idea reformy terytorialno-administracyjnej (2005). Sprzeciw wobec sztucznego, nieskonceptualizowanego procesu scalania jednostek administracyjnych i przymusowego jednoczenia miejscowości wiejskich wyraziły nie tylko władze obwodów i rejonów, przeciwni byli także sami mieszkańcy. Próba reformy skończyła się tak samo szybko, jak się rozpoczęła. Ta próba zreformowania ustroju terytorialno-administracyjnego okazała się dość podatna na odbiór społeczny i skończyła się niepowodzeniem właśnie $z$ tego powodu, że została narzucona odgórnie. Prawdopodobnie kierunek tej reformy, podobnie jak wielu innych, miał być przeciwny - kształtowany oddolnie. Tylko w takich warunkach projekt decentralizacji mógł stać się czynnikiem integrującym społeczeństwo, jednoczącym wysiłki władz i społeczeństwa obywatelskiego w celu optymalizacji tego procesu i osiagnięcia skutecznych wyników. To właśnie $z$ tego powodu dążenie do kolejnego przezwyciężenia „wszechwładztwa” pionowej struktury władzy znalazło odzew wśród społeczeństwa.

7 A.S. Matviênko, Politiko-pravovì zasadi...; Admìnìstrativno-teritorìal'nij ustrì Ukraïni. Problemnì pitannâ ta možlivì varianti ìh virì̌ennâ, zag. red. V.G. Âcuba, Kiïv 2003.

8 Konstituciâ Ukraïni... 
Warto zauważyć, że Ukraina jako pierwszy kraj w przestrzeni postradzieckiej po państwach bałtyckich zdecydowała się na wdrożenie reformy decentralizacji. Do jej przeprowadzenia niezbędna była wola polityczna, gdyż dość ciężko było zrezygnować z zasad zarządzania, które od dekad panowały na obszarze kraju i pozwalały na kontrolę praktycznie wszystkich sfer życia publicznego, przede wszystkim podziału środków budżetowych.

W dniu 1 kwietnia 2014 roku Gabinet Ministrów Ukrainy zatwierdził Koncepcje reformowania samorzadu lokalnego i terytorialnej organizacji władzy na Ukrainie ${ }^{9}$. Przewidywała ona utworzenie instytucji bezpośredniego sprawowania władzy przez obywateli, warunków do zaspokajania interesów obywateli na odpowiednim terytorium oraz zagwarantowania im skutecznego świadczenia usług publicznych poprzez optymalny podział kompetencji między organy samorzadu lokalnego a organy władzy wykonawczej na różnych szczeblach ustroju terytorialno-administracyjnego na zasadach subsydiarności i decentralizacji. We wspomnianym dokumencie władze wyrażają konieczność angażowania mieszkańców w proces podejmowania decyzji i sprzyjania rozwojowi form bezpośredniego sprawowania władzy przez obywateli.

W Koncepcji odnotowywano, że obecnie system samorządu lokalnego nie zaspokaja potrzeb społeczeństwa. Funkcjonowanie jego organów w większości wspólnot terytorialnych nie zapewnia tworzenia i utrzymywania korzystnego środowiska życia niezbędnego do wszechstronnego rozwoju osoby, jej samorealizacji, ochrony jej praw oraz świadczenia przez organy samorządu lokalnego i tworzone przez nie instytucje i organizacje wysokiej jakości usług administracyjnych, społecznych i innych dla mieszkańców na odpowiednich terytoriach. To właśnie na rozwiązanie tych problemów ukierunkowana została reforma decentralizacyjna.

Realizację Koncepcji zaplanowano na lata 2014-2017. Już na etapie przygotowawczym (2014) przewidywano: wprowadzenie zmian do Konstytucji Ukrainy w zakresie utworzenia organów wykonawczych rad obwodowych i rejonowych oraz podziału kompetencji między nimi; przyjęcie aktów legislacyjnych w zakresie wprowadzenia mechanizmu bezpośredniego sprawowania władzy przez obywateli; stwo-

\footnotetext{
9 Pro shvalennâ Koncepcï reformuvannâ mìscevogo samovrâduvannâ ta teritorìal'nö̈ organizaciï vladi v Ukraïnì. Rozporâdžennâ Kabìnetu Mìnìstrìv Ukraïni vìd 1 IV 2014 r., nr 333-r., Verhovna Rada Ukraïni, http://zakon5.rada.gov.ua/laws/show/333-2014-\%D1\% 80 [dostęp: 9 lipca 2020].
} 
rzenie podstawy prawnej do realizacji prawa wspólnot terytorialnych do dobrowolnego łączenia się, przy czym przewidziane jest nadanie wsparcia ze strony państwa dla zjednoczonych wspólnot w ciagu pięciu lat po utworzeniu w celu poprawienia infrastruktury świadczenia usług i dostępności transportowej; stworzenie podstawy prawnej do realizacji prawa wspólnot terytorialnych, do współpracy na zasadach kooperacji w zakresie zasobów i organizacji oraz otrzymania wsparcia państwowego dla realizacji projektów takiej współpracy; legislacyjne uregulowanie nowego systemu ustroju terytorialno-administracyjnego; przeprowadzenie modelowania jednostek administracyjno-terytorialnych $\mathrm{w}$ regionach oraz opracowanie projektów aktów normatywnych niezbędnych do zakończenia tworzenia nowego systemu ustroju terytorialno-administracyjnego itd.

Drugi etap realizacji Koncepcji (zaplanowany na lata 2015-2017) przewidywał m.in.: ujednolicenie i standaryzację usług publicznych świadczonych dla mieszkańców przez organy samorządu lokalnego i organy władzy wykonawczej $z$ uwzględnieniem zasad maksymalnej dostępności usług dla konsumentów oraz określenie na płaszczyźnie prawnej warunków do ich właściwego finansowania; przeprowadzenie instytucjonalnej reorganizacji organów samorządu lokalnego i lokalnych organów władzy wykonawczej na nowej podstawie terytorialnej; przeprowadzenie wyborów lokalnych $z$ uwzględnieniem zreformowanego systemu organów samorządu lokalnego; poprawienie systemu planowania obszarów wspólnot terytorialnych, rozwiazanie kwestii zapewnienia dla nowo utworzonych wspólnot terytorialnych map zagospodarowania i generalnych planów zagospodarowania.

Pomimo faktu, że termin realizacji (dotychczas obowiązującej) Koncepcji reformowania samorzadu lokalnego i terytorialnej organizacji władzy na Ukrainie określony przez Gabinet Ministrów upłynął już w roku 2017, nie złożono żadnego publicznego sprawozdania dotyczącego jej wdrożenia lub konieczności przedłużenia terminu realizacji.

Uchwalona przez rząd Ukrainy Koncepcja miała stać się częścią składową innego ważnego aktu normatywnego - Państwowej strategii rozwoju regionalnego na okres do 2020 roku przyjęta uchwała Gabinetu Ministrów Ukrainy po czterech miesiącach - w sierpniu 2014 roku $^{10}$, ale dokument ten nie zawierał nawet wzmianki o Koncepcji.

10 Pro zatverdžennâ Deržavnoï strategï regional'nogo rozvitku na perìod do 2020 roku. Postanova Kabìnetu Mìnistrìv Ukraïni vìd 6 serpnâ 2014 r., nr 385, Verhovna Rada Ukraïni, http://zakon3.rada.gov.ua/laws/show/385-2014-\%D0\%BF [dostęp: 9 lipca 2020]. 
Symptomatyczne jest także uzasadnienie konieczności przyjęcia uchwały rządowej, na mocy której została uchwalona Państwowa strategia. Ta konieczność, jak zaznaczono w dokumencie, uzasadniona jest: 1) upływem terminu realizacji Państwowej strategii; 2) zmiana zewnętrznych i wewnętrznych warunków rozwoju regionów w ciagu ostatnich siedmiu lat; 3) potrzeba synchronizacji z cyklami planowania i cyklami budżetowymi UE $z$ uwzględnieniem wpływu urbanizacji, wyludnienia obszarów wiejskich, międzynarodowych przepływów siły roboczej oraz kryzysu finansowo-gospodarczego. Oczywiście opracowanie strategii rozwoju tak ważnej sfery działalności polityczno-administracyjnej miało być uzasadnione nie zakończeniem okresu realizacji poprzedniej uchwały rządowej (analiza wykonania której, nawiasem mówiąc, nie stała się przedmiotem debaty publicznej), lecz koniecznością wyznaczenia celów strategicznych rozwoju regionalnego.

Realizacja Państwowej strategii zaplanowana została na dwa okresy. Pierwszy obejmował lata 2014-2016, natomiast drugi - lata 2017-2020. Zrozumiałe jest, że skuteczność tego dokumentu będzie można ocenić dopiero w przyszłości. jednocześnie warto odnotować, że Ukraina już „zakończyła” realizację pierwszego etapu wdrożenia i zbliża się do zakończenia drugiego etapu (2017-2020), który przewiduje realizacje licznych konkretnych działań i osiagnięcie dokładnie określonych „zakładanych wartości wskaźników”. Przykładowo, po realizacji pierwszego etapu (do 2016), zgodnie $z$ zakładanymi wartościami wskaźników, na których osiagnięcie ukierunkowana jest strategia, miał nastapić wzrost szeregu wskaźników rozwoju społeczno-gospodarczego, m.in.:

- wartość PKB per capita wg parytetu siły nabywczej miała wzrosnać (w porównaniu do 2012 roku) z 32002 do 43395 hrywien, czyli o 35,6 proc. ${ }^{11}$;

- realny dochód per capita miał wzrosnąć (w porównaniu do 2013 roku) z 25206 do 28129 hrywien, czyli o 2923 hrywien (11,6 proc.);

- w ciagu lat 2015-2016 oczekiwano wzrost bezpośrednich inwestycji zagranicznych o 66 USD per capita (średnio o 5 proc. w skali kraju, podczas gdy na przykład w obwodach charkowskim oraz iwanofrankiwskim wartości te miały wzrosnąc odpowiednio o 62,9 proc. i 14,9 proc.);

${ }_{11} \mathrm{Tu}$ i dalej obliczenia na podstawie: Deržavna strategiâ regional'nogo rozvitku na period do 2020 roku. Dodatok 5, Verhovna Rada Ukraïni, http:/ / zakon3.rada.gov.ua/laws/ show/385-2014-\%D0\%BF [dostęp: 9 lipca 2020]. 
- zakładano, że wartość eksportu towarów per capita wzrośnie o 319 USD, czyli o 22,9 proc.;

- do końca 2016 roku liczba średnich przedsiębiorstw miała wzrosnać o 25 proc., a liczba małych przedsiębiorstw o 11,8 proc.;

- planowano zwiększenie udziału sprzedaży produktów innowacyjnych o 63,6 proc.;

- o 26,6 proc. miało wzrosnać średnie miesięczne wynagrodzenie nominalne;

- o 7 proc. miały wzrosnąć wskaźniki liczby lekarzy wszystkich specjalności na 10 tys. mieszkańców;

- współczynnik objęcia dzieci wychowaniem przedszkolnym na terenach wiejskich i miejskich w porównaniu do początkowego 2012 roku miał wzrosnać odpowiednio o 13,2 proc. i 2,8 proc.

Ponadto planowano istotne zwiększenie gęstości utwardzonych dróg publicznych, oczekiwano spadku stopy bezrobocia, zmniejszenia śmiertelności mieszkańców itp.

Nawet pobieżna analiza treści strategii rozwoju kluczowego kierunku reform w obecnych warunkach społeczno-politycznych wywołuje watpliwości co do możliwości osiagnięcia zakładanych celów i wskaźników. Spadek gospodarczy na tle agresji zbrojnej, wzrost inflacji, permanentny kryzys systemu bankowego kraju, wzrost stawek za media oraz usługi komunalne i telekomunikacyjne jak dotą nie daja podstaw do oczekiwania, że zakładane w Państwowej strategii rozwoju regionalnego wskaźniki zostaną osiagnięte w zaplanowanym terminie.

Innymi słowy, należy przyznać, że zrozumiałe, systemowe, uzasadnione zasady i sposoby kompleksowego rozwiazania problemu decentralizacji nie zostały zaproponowane. Zaistniało natomiast realne niebezpieczeństwo, że wobec braku wyważonej polityki regionalnej i skutecznych działań na rzecz wzmocnienia samorządu lokalnego kompleksowe reformowanie tej ważnej sfery administracji publicznej może być dokonywane wyłącznie ze względów politycznych. „Decentralizacja" jako proces i wynik transformacji, jako kompleksowe zjawisko (którego niezbędnymi składowymi sa analiza i prognoza polityczna, zdefiniowanie skutecznych kierunków działalności i opracowanie konsekwentnego, konstruktywnego i racjonalnego planu przedsięwzięć itp.) nie stała się bowiem, jak dotąd, przedmiotem wszechstronnego badania naukowego i praktycznego wdrożenia. To właśnie $z$ tego powodu zarówno badania naukowe, jak i praktyka staja przed koniecznościa systemowej, wszechstronnej analizy istoty, treści i form 
decentralizacji oraz opracowania sposobów jej kompleksowego przeprowadzenia skierowanych na zapobieganie biurokracji i woluntaryzmowi w tej kwestii.

Koncepcja decentralizacji, w opinii ukraińskich badaczy ${ }^{12}$, zawiera cały szereg ryzyk spowodowanych przede wszystkim decentralizacją budżetu, która może: minimalizować skuteczność kontroli władz centralnych nad procesem budżetowym na poziomie lokalnym; pogłębiać zróżnicowanie poziomów rozwoju regionów; sprzyjać wzrostowi korupcji w przypadku, gdy konkurencja polityczna na poziomie lokalnym będzie ograniczona; powodować zwiększenie wydatków na świadczenie usług społecznych na małych obszarach ${ }^{13}$. Poza tym należy uwzględnić już istniejącą dysproporcję w poziomach rozwoju regionów i wspólnot terytorialnych. Szczególną uwagę należy zwrócić na przezwyciężenie korupcji w funkcjonowaniu organów samorządu lokalnego. Doświadczenia światowe wskazują na niecelowość przeprowadzenia procesów decentralizacji $\mathrm{w}$ warunkach wysokiego poziomu korupcji ${ }^{14}$.

Warto odnotować, że wiedza Ukraińców w zakresie reformy decentralizacji pozostaje na dość niskim poziomie. Świadczą o tym wyniki badań ankietowych przeprowadzonych przez Fundację „Demokratyczne Inicjatywy" i Kijowski Międzynarodowy Instytut Socjologii w latach 2016 i $2017^{15}$. Wyniki badañ ${ }^{16}$ zaprezentowano w tabelach 1-3.

Najwięcej wiedzą o reformie w centralnej części kraju (ogółem 87 proc.), najmniej - na południu Ukrainy (69 proc.). Większość Ukraińców (42 proc.) pozytywnie odbiera samą ideę decentralizacji. Negatywny stosunek do działalności władz w tej sferze ma 27 proc. badanych (tabela 2). Najwięcej zwolenników reformy jest na zachodzie

12 O. Kuhlenko, R. Fedorâk, S. Nevmeržicka, Problemi decentralizacï vladi u mežah regional'noï politiki Ukraïni, „Deržavne upravlìnnâ: udoskonalennâ ta rozvitok” 2017, nr 2, http: / / www.dy.nayka.com.ua/?op=1\&z=1028 [dostęp: 9 lipca 2020].

13 G.V. Voznâk, Perevagi ta riziki bûdžetnoï decentralizaciï: teoretiko-metodologičnì aspekti, „Problemi ekonomiki” 2015, nr 2, s. 253-257.

14 O. Kuhlenko, R. Fedorâk, S. Nevmeržic ka, Problemi decentralizacji...

15 Gromads'ka dumka naselennâ sodo reformi decentralizacï. Pres-relìz, Fond „Demokratičnì ìnìciativi” ìm. İl'ka Kučeriva, 24 VII 2017, https://dif.org.ua/article/gromadska -dumka-naselennya-shchodo-reformi-detsentralizatsii [dostęp: 9 lipca 2020].

16 Ogólnokrajowe badanie ankietowe mieszkańców Ukrainy zostało przeprowadzone przez Fundację „Demokratyczne Inicjatywy” im. Ilka Kuczeriwa wspólnie ze służbą socjologiczną Centrum Razumkowa w dniach 9-13 VI 2017 r. we wszystkich regionach Ukrainy z wyjątkiem Krymu i okupowanych części obwodów donieckiego i ługańskiego. Badania przeprowadzono na grupie 2018 ankietowanych w wieku od 18 lat, błąd próby nie przekracza 2,3 proc. Wykorzystano również wyniki badania ankietowego przeprowadzonego przez Fundację „Demokratyczne Inicjatywy” i Kijowski Międzynarodowy Instytut Socjologii w sierpniu 2016 r. 
kraju (48 proc.), najmniej - na wschodzie (31 proc.). $Z$ innej strony jedynie 12 proc. Ukraińców jest zupełnie zadowolonych $z$ tempa reformy, 37 proc. uważa, że jest wdrażana zbyt powoli, a 22 proc. - że nie odbywa się w ogóle.

\section{TABELA 1}

Odpowiedzi na pytanie: „Czy wie Pan/Pani o inicjatywach władz w zakresie decentralizacji władzy na Ukrainie?” (w \%)

\begin{tabular}{|l|c|c|}
\hline \multicolumn{1}{|c|}{ Odpowiedzi } & VIII 2016 & VI 2017 \\
\hline Tak, dobrze wiem & 12,0 & 19,9 \\
Coś słyszałem/-am na ten temat & 54,1 & 61,9 \\
Nie, nie wiem & 30,8 & 18,0 \\
Trudno powiedzieć & 3,1 & - \\
Brak odpowiedzi & - & 0,2 \\
\hline
\end{tabular}

TABELA 2

Odpowiedzi na pytanie: „Czy popiera Pan/Pani działania podejmowane przez władze w zakresie decentralizacji władzy?” (w \%)

\begin{tabular}{|l|c|c|}
\hline \multicolumn{1}{|c|}{ Odpowiedzi } & VIII 2016 & VI 2017 \\
\hline Zdecydowanie tak & 9,5 & 7,5 \\
Raczej tak & 21,9 & 34,5 \\
Raczej nie & 13,7 & 16,3 \\
Zdecydowanie nie & 9,3 & 10,4 \\
Nic nie wiem na ten temat & 27,4 & - \\
Trudno powiedzieć & 18,3 & 31,4 \\
\hline
\end{tabular}

Ponad połowa ankietowanych (55 proc.) nie odczuła zmian na skutek wykorzystania dodatkowych środków otrzymanych przez budżety lokalne w ciagu ostatnich lat. Przy tym odsetek tych, którzy odczuli zmiany na lepsze, i tych, którzy odczuli zmiany na gorsze, jest ten sam - 16 proc. Przewage tych, którzy zauważyli zmianę na lepsze, odnotowano na zachodzie (24 proc. w porównaniu do 12 proc.) i na wschodzie kraju (17 proc. w porównaniu do 15 proc.), podczas gdy $\mathrm{w}$ innych regonach jest więcej osób, które odczuły zmiany na gorsze (19 proc. w porównaniu do 14 proc. odczuwających zmiany na lepsze w centrum kraju i 21 proc. w porównaniu do 11 proc. odpowiednio na południu). 
Wśród tych, którzy zauważyli zmiany na lepsze, najwięcej osób (64 proc.) odpowiedziało, że te zmiany dotyczyły podniesienia jakości dróg. Dość często respondenci, którzy odczuli zmiany na lepsze, wymieniali w tym kontekście poprawę zagospodarowania terenów (30 proc.), poprawę warunków dla spędzania czasu wolnego (25 proc.), prace $\mathrm{w}$ zakresie gospodarki komunalnej (23 proc.) i funkcjonowanie komunikacji publicznej (20 proc.).

Największy odsetek tych, którzy odczuli zmiany na gorsze, wskazał na spadek jakości usług medycznych - 53 proc. Negatywne zmiany dotyczyły także innych dziedzin - opieki nad grupami wrażliwymi społecznie (44 proc.) i zapewnienia miejsc pracy dla obywateli (39 proc.). Charakterystyczne jest, że w opinii 38 proc. tych, którzy zauważyli zmiany na gorsze, pogorszenia dotyczyły także jakości nawierzchni dróg.

Jednocześnie nieco osłabło przekonanie mieszkańców o tym, że władze lokalne potrafia dobrze wykorzystać większe uprawnienia, które zyskają na skutek decentralizacji (tabela 3). Absolutną pewność co do tego wyraża 10 proc. badanych, raczej przekonanych o tym jest 32 proc., podczas gdy 29 proc. ma co do tego istotne watpliwości, zaś 17 proc. jest przekonanych, że władze lokalne tego nie potrafią. W największym stopniu przekonani co do możliwości swoich władz lokalnych sa mieszkańcy regionu zachodniego (50 proc.), w najmniejszym zaś - mieszkańcy południa kraju (32 proc.).

\section{TABELA 3}

Wyniki odpowiedzi na pytanie: „Czy Pana/Pani zdaniem władze lokalne w Pana/Pani miejscowości potrafią sprostać zadaniom, jeśli na skutek decentralizacji zyskają większe uprawnienia i odpowiedzialność?" (w \%)

\begin{tabular}{|l|c|c|}
\hline \multicolumn{1}{|c|}{ Odpowiedzi } & VIII 2016 & VI 2017 \\
\hline Jestem przekonany/-a, że nasze władze lokalne całkowicie & & \\
potrafia uporać się $\mathbf{Z}$ większymi uprawnieniami & 15,4 & 10,3 \\
Sądzę, że na ogół potrafią & 36,8 & 31,6 \\
Istnieja poważne wațliwości, że potrafia & 20,1 & 29,0 \\
Jestem przekonany/-a, że nasze władze lokalne & & \\
nie potrafią uporać się $\mathbf{Z}$ większymi uprawnieniami & 10,1 & 16,8 \\
Trudno powiedzieć & 17,6 & 12,3 \\
\hline
\end{tabular}

Obywatele wyrazili także opinię na temat ewentualnych pozytywnych i negatywnych skutków decentralizacji. 24 proc. badanych uważa, że da ona obywatelom nowe możliwości wpływu na władze, 
a 18 proc. sądzi, że dzięki tej reformie poprawi się jakość świadczonych usług. Natomiast 28 proc. ma obawy, że decentralizacja doprowadzi do pojawienia się lokalnych „kacyków”, a 16 proc. - do spustoszenia wsi i osad. Największe obawy co do lokalnych „kacyków” wyrażano na wschodzie kraju (38 proc.), natomiast największe możliwości w zakresie oddziaływania na władze zauważyli mieszkańcy regionu zachodniego (32 proc.).

Krajowe doświadczenia $\mathrm{w}$ dziedzinie transformacji społecznej świadcza o tym, że próby reform politycznych i prawnych za każdym razem aktualizuja problemy: decentralizacji, rozwoju systemu samorządu lokalnego i organizacji władzy terytorialnej. Faktycznie czas wprowadzania decentralizacji wystartował wraz $z$ próbą kolejnych zmian ustroju terytorialno-administracyjnego, która stało się przyjęcie w lutym 2015 roku ustawy O zasadach państwowej polityki regionalnej ${ }^{17}$ oraz ustawy $O$ dobrowolnym jednoczeniu sie wspólnot terytorialnych $^{18}$. Ta ostatnia próba koncepcyjnie różni się od tej z 2005 roku tym, że ma opierać się na inicjatywie oddolnej. Jednocześnie trzeba przyznać, że nie zorganizowano kampanii informacyjnej na miarę projektu o tak dużej skali skierowanego na istotne zmiany w systemie samorzadu lokalnego. Jeszcze nie wszyscy obywatele dobrze rozumieja istotę tej reformy i sa świadomi jej skutków politycznych, społeczno-gospodarczych i prawnych ${ }^{19}$.

Ogólnie rzecz biorac, ustawa $O$ dobrowolnym jednoczeniu sie nie uwzględniała licznych aspektów procesów łączenia się wspólnot, co $\mathrm{w}$ praktyce spowodowało realne problemy, na które zwracali uwage m.in. eksperci Głównego Wydziału Prawnego Aparatu Rady Najwyższej Ukrainy. Co prawda, cześć uchybień usunięto poprzez wprowadzenie zmian i poprawek w latach 2015-2017, ale wiele problemów do dziś pozostaje do rozwiazania.

Ponadto warto zwrócić uwagę na niedostosowanie treści poszczególnych artykułów ustawy $O$ dobrowolnym jednoczeniu się wspólnot terytorialnych do Konstytucji Ukrainy. Chodzi m.in. o to, że możliwość łączenia się we wspólnoty terytorialne mają nie tylko wsie, lecz także osady i miasta. Jednocześnie art. 140 ust. 1 Konstytucji Ukrainy ${ }^{20}$

17 Zakon Ukraïni „Pro zasadi deržavnoï regional'noï politiki”, Verhovna Rada Ukraïni, http://zakon.rada.gov.ua/laws/show/156-19 [dostęp: 9 lipca 2020].

18 Zakon Ukraïni "Pro dobrovil'ne ob êdnannâ teritorìal'nih gromad”, Verhovna Rada Ukraïni, http://zakon.rada.gov.ua/laws/show/157-19 [dostęp: 9 lipca 2020].

19 O. Berezûk, Zakon pro OTG: „plûsi” ta „mìnusi”, „Den"” 23 VI 2017, https://day.kyiv. $\mathrm{ua} / \mathrm{uk} / \mathrm{blog} /$ polityka/zakon-pro-otg-plyusy-ta-minusy [dostęp: 9 stycznia 2020].

${ }^{20}$ Konstituciâ Ukraïni... 
definiuję wspólnotę terytorialną wyłącznie jako „dobrowolne zrzeszenie we wspólnotę wiejska mieszkańców kilku wsi", które powinno mieć status jednostki administracyjno-terytorialnej. Wychodząc $z$ treści art. 33 ust. 1 , art. 140 ust. 1 i 3, art. 141 oraz art. 143 ust. 1 Konstytucji, system samorządu lokalnego (którego pierwotnym podmiotem jest wspólnota terytorialna) tworzony jest poprzez zjednoczenie $z$ uwzględnieniem istniejącego (art. 133 Konstytucji) podziału integralnego terytorium państwa na jednostki administracyjno-terytorialne. To właśnie te, zdefiniowane w art. 133 jednostki terytorialne powinny być podstawa przestrzenna do tworzenia wspólnot terytorialnych i organów samorządu lokalnego, a także organów państwowych, a nie odwrotnie. Innymi słowy, struktura wspólnot terytorialnych powinna odpowiadać systemowi ustroju terytorialno-administracyjnego. Nieunormowana pozostaje sytuacja jednoczesnego funkcjonowania obok siebie nowych organów wybieralnych zjednoczonych wspólnot terytorialnych (ZWT) oraz rejonowych administracji państwowych i rad rejonowych, co stwarza możliwość wystapienia sprzeczności między „nowymi” a „starymi” organami władzy w terenie. Taki stan rzeczy powoduje dublowanie kompetencji rady rejonowej i rejonowej administracji państwowej $z$ jednej strony $i$ organów samorzadu lokalnego zjednoczonych wspólnot terytorialnych $z$ drugiej strony, a także spadek jakości świadczenia usług $z$ powodu zmniejszenia finansowania budżetu rejonu w części subwencji medycznej i oświatowej. Dualizm władzy na poziomie samorzadu lokalnego ma negatywny wpływ na procesy podziału mienia komunalnego między ZWT a rejonami oraz komplikuje kwestię właściwości organów władzy wykonawczej na terenach zjednoczonych wspólnot terytorialnych utworzonych w granicach różnych rejonów.

Ustawa O dobrowolnym jednoczeniu się wspólnot terytorialnych zawiera przepis, zgodnie $z$ którym to jednoczenie powinno się odbywać na zasadzie dobrowolności. Zainicjować ten proces moga tylko mieszkańcy tych wspólnot. Ustawa nadaje prawo do jego zainicjowania jednoosobowym organom wykonawczym wsi, osad i miast lub co najmniej $1 / 3$ ogólnej liczby radnych rady lokalnej. Wiodaca rolę $\mathrm{w}$ tym procesie powierzono zatem organom przedstawicielskim i wykonawczym samorzadu lokalnego. Jednocześnie, jak wynika $z$ tempa wdrożenia reformy samorządu lokalnego, widoczne sa skutki istniejącej do dziś praktyki scentralizowanego systemu administracji państwowej - zdecydowana większość przedstawicieli lokalnych organów władzy wciaż̇ czeka na polecenia odgórne. Ustawa przewiduje dość skompli- 
kowana (nieograniczona czasowo) procedurę konsultacji społecznych, utworzenie wspólnych grup roboczych oraz zbadanie propozycji co do zgodności z Konstytucja i ustawodawstwem Ukrainy przez obwodowa administrację państwowa (OAP). W przypadku pozytywnej opinii OAP podejmuje decyzję o utworzeniu zjednoczonej wspólnoty terytorialnej. Obwodowa administracja państwowa występuje do Centralnej Komisji Wyborczej o zarządzenie pierwszych wyborów przewodniczącego i radnych zjednoczonej wspólnoty terytorialnej.

Rzecz jasna, bez należytego wsparcia informacyjnego, metodycznego i prawnego, bez uświadomienia sobie przez samych mieszkańców wspólnot norm i wymogów ustawy (a bez zgody większości mieszkańców skuteczne zakończenie procesu zjednoczenia wspólnot terytorialnych nie jest możliwe) zorganizowanie tego przedsięwzięcia okazało się dość skomplikowane. Co prawda, wiedza obywateli w zakresie procesu dobrowolnego jednoczenia się wspólnot w porównaniu do wyników badań z poprzedniego roku nieco wzrosła. Prawie 18 proc. badanych dobrze wie o nim (w porównaniu do 12 proc. w 2016 r.), a 56 proc. - coś słyszało (46 proc. w 2016). 26 proc. Ukraińców wciąż nic nie wie na ten temat. Poziom wiedzy o procesie jednoczenia się wspólnot jest praktycznie ten sam na zachodzie, wschodzie i w centrum kraju (dobrze wie lub coś słyszało o nim odpowiednio 74, 75 i 78 proc. badanych) oraz jest zauważalnie mniejszy na południu $(59 \text { proc. })^{21}$.

Nieścisłości i sprzeczności w obowiązującej ustawie były powodem licznych apeli zjednoczonych wspólnot terytorialnych i przewodniczących lokalnych rad do Rady Najwyższej Ukrainy i Gabinetu Ministrów Ukrainy w sprawie skutków dobrowolnego jednoczenia się wspólnot terytorialnych, podstaw do uznania ich prawomocności itp. Komisja Rady Najwyższej ds. Rozbudowy Państwa, Polityki Regionalnej i Samorządu Lokalnego oraz Ministerstwo Rozwoju Regionalnego, Budownictwa i Gospodarki Komunalnej Ukrainy zmuszone były do udzielenia specjalnych wyjaśnień w sprawie przepisów ustawy oraz ich realizacji.

W 2015 roku, w okresie mniej niż pół roku obowiąywania ustawy O dobrowolnym jednoczeniu się wspólnot terytorialnych, utworzono 159 takich wspólnot, zaś w 2016 roku - następnych 198. Zgodnie ze stanem na dzień 1 listopada 2018 roku na Ukrainie utworzono 674 zjednoczonych wspólnot terytorialnych, w $478 \mathrm{z}$ nich (71 proc.) wybrano rady zjednoczonych wspólnot. Proces zjednoczenia został

${ }^{21}$ Gromads'ka dumka naselennâ sodo reformi decentralìzacï... 
całkowicie zakończony w 14 rejonach, zaś w $8 \mathrm{z}$ nich zjednoczone wspólnoty terytorialne całkiem „pochłonęły” ich terytoria. Jednocześnie warto zauważyć, że wyniki badań socjologicznych wskazuja na to, że większość mieszkańców zjednoczonych wspólnot (63 proc.) do dziś nie odczuła pozytywnych zmian w warunkach życia ${ }^{22}$.

Oczywiście procesowi decentralizacji i reformowania samorządu lokalnego powinna cały czas towarzyszyć jego analiza, ujawnianie zachodzących w nim sprzeczności, stworzenie mechanizmów służących zapobieganiu konfliktom i ich rozwiazywaniu. Zresztą należy pokonać trudna drogę realnych działań w kierunku zwiększenia samodzielności regionów, rozszerzenia kompetencji władz lokalnych i regionalnych. Pomyślne zakończenie procesu dobrowolnego jednoczenia się wspólnot terytorialnych wymaga nie tylko reformy ustawodawstwa, lecz także zmiany społeczno-psychologicznego nastawienia obywateli, zwiększenia ich roli $\mathrm{w}$ procesie zarządzania sprawami państwa. Będzie ono zreszta miało ważne znaczenie dla przeformatowania obecnego systemu administracji państwowej, dla usprawnienia praktycznego funkcjonowania organów władzy państwowej, organów samorządu lokalnego i społeczeństwa w ogóle.

W tym kontekście zyskała na aktualności potrzeba uchwalenia ustawy o ustroju terytorialno-administracyjnym i wprowadzenia odpowiednich zmian do Konstytucji Ukrainy. W dniu 21 lutego 2018 roku Gabinet Ministrów Ukrainy zaakceptował projekt ustawy O zasadach podziału administracyjno-terytorialnego Ukrainy i podją decyzję o skierowaniu go do Rady Najwyższej ${ }^{23}$. Projekt ustawy proponuje określenie zasad podziału administracyjno-terytorialnego Ukrainy i tryb utworzenia, likwidacji, wytyczenia i zmiany granic jednostek administracyjno-terytorialnych. Wprawdzie Główny Wydział Prawny Aparatu Rady Najwyższej Ukrainy zgłosił liczne uwagi do projektu ustawy i zalecił, aby po pierwszym czytaniu skierować projekt ustawy do dalszych prac.

Doświadczenie pokazuje, że zmianom struktury podziału administracyjno-terytorialnego praktycznie zawsze towarzyszą zarówno pozytywne (wzrost skuteczności współpracy między różnymi jednostkami terytorialnymi i poziomami zarzadzania, podniesienie jakości świadczonych usług publicznych), jak i negatywne (gospodarcze, poli-

\footnotetext{
22 Ibidem.

${ }^{23}$ Kabmin shvaliv zakonoproekt pro administrativno-teritorial'nij ustrij Ukraïni, RBKUkraïna, 21 II 2018, https://www.rbc.ua/ukr/news/kabmin-odobril-zakonoproekt-administrativno-1519218347.html [dostęp: 9 lipca 2020].
} 
tyczne, kulturowe) skutki. Przewidzenie i minimalizacja negatywnych przejawów zmiany ustroju terytorialno-administracyjnego możliwe jest jedynie pod warunkiem uwzględnienia całego kompleksu czynników wewnętrznych i zewnętrznych, ich zależności od ogólnopaństwowych procesów, ogólnoeuropejskiego kontekstu i ogólnoświatowego rozwoju.

Kluczowym i pod wieloma względami decydującym zadaniem obecnego etapu rozbudowy państwa jest doskonalenie funkcjonowania wszystkich gałęzi władzy, usprawnienie mechanizmu, struktury i funkcji administracji państwowej, jej decentralizacja. Wszystko to powinno być skierowane na integrację społeczna poprzez: tworzenie na Ukrainie jedynego narodu politycznego, optymalizację relacji między centrum a regionami, rozwijanie samorzadu lokalnego, kształtowanie się społeczeństwa obywatelskiego oraz sprzyjanie funkcjonowaniu jego instytucji. Jednocześnie powodzenie i skuteczność reform zależą przede wszystkim od ich postrzegania przez obywateli, ich aktywności oraz gotowości do dokonania zmian.

Wyodrębnienie cech charakterystycznych i współczesnych tendencji w terytorialnej organizacji struktury władzy, podziału kompetencji między rożne jej poziomy i wzajemnych relacji między nimi pozwala na wysnucie pewnych wniosków oraz określenie możliwych kierunków, sposobów i form usprawnienia tych procesów.

- Forma unitarna państwa potrzebuje usprawnienia pod kątem politycznym i organizacyjnym, ale jej radykalna zmiana nie ma należytych historycznych, społeczno-kulturowych, mentalnych prawnych lub żadnych innych podstaw. Próby zmiany formy ustroju państwa moga spowodować zagrożenia dla porządku konstytucyjnego na Ukrainie. Należy położyć kres wszelkim inicjatywom w zakresie dyskusji publicznych na temat federalizacji i za pomoca szerokiej akcji informacyjnej w mediach zapobiec wykorzystaniu idei „federalizacji” przez siły prorosyjskie, m.in. w okresie przedwyborczym.

- Ważne jest, aby nie dopuścić do zastapienia idei decentralizacji idea regionalizacji, ponieważ koncepcja decentralizacji polega na tym, że część uprawnień i zasobów przekazywana jest wspólnotom terytorialnym przy zachowaniu kontroli nad sektorami prawa i bezpieczeństwa oraz resortami siłowymi na poziomie ogólnopaństwowym, podczas gdy koncepcja regionalizacji zakłada koncentrację zasobów i kompetencji na poziomie regionu, co może doprowadzić do konfrontacji między władzami państwowymi a regionalnymi, a w ostateczności do utraty suwerenności przez państwo. 
- Przy bezwarunkowym zachowaniu unitarności jako ustanowionej w Konstytucji formy ustroju państwa należy podjać kroki w kierunku jej konkretyzacji i rozwoju w kontekście współczesnych procesów społeczno-politycznych, konieczności przeciwstawienia się zagrożeniu zewnętrznej agresji zbrojnej, przezwyciężania przejawów separatyzmu w poszczególnych regionach Ukrainy, uporzadkowania i harmonizacji stosunków międzyetnicznych i międzywyznaniowych, usprawnienia mechanizmu i optymalizacji struktury i funkcji administracji państwowej jako podstawy organizacyjno-politycznej ustroju państwa, a także skutecznego wdrożenia reformy decentralizacji. Wymaga to kompleksowego programu rozwoju współpracy władz centralnych i lokalnych, udoskonalenia wsparcia legislacyjnego dla procesu decentralizacji, m.in. uregulowania niektórych sprzeczności w relacjach między administracjami państwowymi a zjednoczonymi wspólnotami terytorialnymi, a także w określeniu zasad poziomej współpracy między tymi wspólnotami.

- Jak dotąd tworzenie zjednoczonych wspólnot terytorialnych zasadniczo nie cieszy się szerokim poparciem ze strony mieszkańców na skutek braku rozumienia samego procesu decentralizacji, jego celu oraz oczekiwanych skutków. Obywatele sa słabo informowani o zasadach i celach decentralizacji. Działania w zakresie informowania obywateli powinny być prowadzone $\mathrm{w}$ celu nakreślenia perspektyw wdrożenia reformy decentralizacji $z$ wykorzystaniem najlepszych doświadczeń już zjednoczonych wspólnot - obywatelom należy ukazać korzyści płynące dla nich $z$ dobrowolnego jednoczenia się wspólnot terytorialnych. Wszystko to warunkuje konieczność i celowość opracowania całościowej koncepcji wsparcia informacyjnego dla reformy decentralizacji.

- Informacyjne, edukacyjne, komunikacyjne i organizacyjno-polityczne zasoby państwa powinny być skierowane na kształtowanie społecznie znaczących wartości, sensów, wizji przyszłości jako koniecznego warunku jedności społeczeństwa ukraińskiego w sferze wartości. Bardzo ważne pod tym względem jest kształtowanie w świadomości społecznej rozumienia przyczyn i skutków współczesnych zjawisk i procesów, zdefiniowanie perspektyw i sposobów ich realizacji. Otwartość, przejrzystość i konsekwencja władz będą miały decydujące znaczenie dla zachowania jedności społecznej i mobilizacji w celu przezwyciężenia kryzysu społeczno-politycznego. Brak klarownej artykulacji wizji strategicznej reform, podstawowych kierunków i zasad dezorientuje społeczeństwo, stwarza przesłanki do kierowania energii społeczeństwa w różne strony. 
- W celu skutecznego wykorzystania finansowych i kadrowych zasobów zjednoczonych wspólnot terytorialnych niezbędne jest podjęcie działań w zakresie kształcenia i doskonalenia odpowiednich kadr.

- Biorac pod uwagę obecność wysokiego ryzyka działań korupcyjnych w zakresie wykorzystania zasobów finansowych, planowania oraz wykonania budżetów lokalnych, należy przewidzieć wprowadzenie mechanizmów kontroli nad działalnością organów samorządu lokalnego zarówno ze strony organów państwowych, jak i społeczeństwa.

- W obecnych warunkach rozwoju społecznego zyskała na aktualności potrzeba uchwalenia ustawy o ustroju terytorialno-administracyjnym i wprowadzenia odpowiednich zmian do Konstytucji Ukrainy. Praktyka realizacji reformy administracyjno-terytorialnej na płaszczyźnie polityczno-administracyjnej powinna być skierowana na wzmocnienie procesów decentralizacji władzy $z$ uwzględnieniem regionalnych odmienności oraz tożsamości kulturowej, gospodarczej, historycznej i politycznej. Nieuwzględnienie tych odmienności, próby przeprowadzenia zmian kierowane wyłącznie celowościa polityczną wobec braku wyważonej polityki regionalnej i skutecznych form wzmocnienia samorzadu lokalnego stwarzają realne zagrożenie dyskredytacji idei decentralizacji i reformowania tej ważnej sfery polityczno-administracyjnej.

Z języka ukraińskiego przełożył Andrij Saweneć 